\title{
KARAKTERISTIK DAN PSIKOLOGI KONSUMEN TERHADAP KEPUTUSAN PEMBELIAN KEMBALI PRODUK MELALUI E-COMMERCE
}

\author{
Achmad Choiri Alfan
}

Universitas Airlangga

\begin{abstract}
The use of the internet as a means to obtain information can also be used as a business activity or commonly known as Electronic Commerce (e-commerce). E-Commerce is mostly done for sales and service products directly from business organizations with consumers. The use of e-commerce is a necessity of modern business organizations that are used for business development. The combination of characteristics and consumer psychology can encourage consumers to make purchasing decisions. The method used in this study is a quantitative method. The sampling technique in this study used accidental sampling technique. The results of this study are consumer characteristics and consumer psychology simultaneously have a significant effect on repurchase decisions. Whereas the characteristics of consumers and consumer psychology have no partial effect on repurchase decisions using e-commerce.
\end{abstract}

Keywords : E-commerce, consumer characteristics, consumer psychology, purchasing decisions Correspondence : achmadchoirialfan1@gmail.com

\begin{abstract}
ABSTRAK
Penggunaan internet sebagai sarana untuk mendaptkan informasi juga dapat digunakan sebagai aktivitas bisnis atau yang biasa dikenal dengan Electronic Commerce (e-commerce). ECommerce banyak dilakukan untuk penjualan dan pelayanan produk secara langsung dari organisasi bisnis dengan konsumen. Penggunaan e-commerce merupakan kebutuhan dari organisasi bisnis modern yang digunakan untuk pengembangan usaha. Perpaduan antara karakteristik dan psikologi konsumen dapat mendorong konsumen dalam melakukan keputusan pembelian. Metode yang digunakan dalam penelitian ini adalah metode kuantitatif. Teknik pengambilan sampel pada penelitian ini menggunakan teknik accidental sampling. Hasil dari penelitian ini adalah karakteristik konsumen dan psikologi konsumen berpengaruh signifikan secara simultan terhadap keputusan pembelian kembali. Sedangkan karateristik konsumen dan psikologi konsumen tidak berpengaruh secara parsial terhadap keputusan pembelian kembali menggunakan e-commerce.
\end{abstract}

Kata kunci : E-commerce, karateristik konsumen, psikologi konsumen, keputusan pembelian Korespondensi : achmadchoirialfan1@gmail.com

\section{PENDAHULUAN / INTRODUCTION}

Perkembangan teknologi informasi dari waktu ke waktu semakin berkembang pesat, dampak perkembangan teknologi informasi telah merubah perilaku masyarakat yang sederhana menjadi masyarakat modern.
Saat ini untuk memperoleh infomasi bisa didapatkan dengan mudah dan murah dengan adanya perkembangan teknologi informasi. Informasi tentang pendidikan, kesehatan, hiburan, dunia kerja dan dunia bisnis serta 
komunikasi tidak ada lagi batasan waktu dan tempat dengan hadirnya media online, gadget dan jaringan internet yang sangat mudah, sehingga seluruh informasi bisa didapatkan dengan mudah.

Penggunaan internet sebagai sarana untuk mendaptkan informasi juga dapat digunakan sebagai aktivitas bisnis atau yang biasa dikenal dengan Electronic Commerce (e-commerce). E-commerce banyak dilakukan untuk penjualan dan pelayanan produk secara langsung dari organisasi bisnis dengan konsumen. Pengguna e-commerce saat ini telah mengalami peningkatan, hal ini dapat dilihat dengan banyak World Wide Web (www) yang digunakan sebagai media pelayanan dan penjualan online. Penggunaan e-commerce merupakan kebutuhan dari organisasi bisnis modern yang digunakan untuk pengembangan usaha. E-commerce memiliki berbagai manfaat baik untuk konsumen dan organisasi bisnis, diantaranya manfaat e-commerce bagi konsumen adalah konsumen tidak perlu datang langsung ke toko untuk melakukan pembelian barang yang diinginkan dan konsumen dapat bertransaksi selama 24 jam serta konsumen dapat menghemat biaya apabila lokasi toko jauh karena dapat diganti dengan biaya pengiriman yang lebih murah. Manfaat e-commerce bagi organisasi bisnis diantaranya dapat menghemat biaya promosi, dapat menjangkau pasar yang lebih luas dan menghemat biaya untuk menyewa toko, karena tanpa menyewa toko organisasi bisnis masih bisa berjalan. Perkembangan bisnis menggunakan $e$ commerce dilakukan untuk meningkatkan serta memenangkan persaingan bisnis dan penjualan produk, karena dengan menggunakan e-commerce kegiatan jual beli dan pemasaran lebih efisien dan efektif dengan mempermudah dan mempercepat proses bertransaksi. Kualitas transfer data pembelian juga menjadi lebih baik daripada menggunakan proses manual, karena tidak dilakukan input ulang data yang memungkinkan terjadi human error.

Kegiatan transaksi pembelian (berbelanja) secara online di Indonesia saat ini tidak hanya dilakukan oleh wanita saja tetapi sudah menjadi pola hidup masyarakat Indonesia, dimana laki- laki mulai aktif dalam transaksi pembelian sehingga hal tersebut mengakibatkan terjadinya budaya konsumtif. Ada beberapa faktor yang mempengaruhi seseorang dalam membeli sebuah produk secara online. Sesorang terdorong membeli sebuah produk karena adanya rasa takut, ketakutan merupakan pendorong yang sangat kuat. Contoh, karena takut melakukan perjalanan ke toko dengan resiko macet dan terjadi kecelakaan, sesorang melakukan transaksi pembelian secara online untuk efisien dan efektifitas waktu dan biaya. Disamping itu, hal yang mendorong seseorang untuk melakukan pembelian adalah sesorang ingin mengikuti trend berbelanja secara online. Perilaku pembelian konsumen dipengaruhi beberapa faktor, Kotler dan Keller (2009) menjelaskan perilaku pembelian konsumen dipengaruhi oleh faktor budaya, sosial dan pribadi, serta empat proses psikologi kunci yaitu motivasi, persepsi, pembelajaran dan memori mempengaruhi respon konsumen secara fundamental. Dari definisi tersebut dapat dikatakan bahwa perpaduan antara karakteristik dan psikologi konsumen dapat mendorong konsumen dalam melakukan keputusan pembelian.

\section{Kajian Pustaka Marketing Mix}

Menurut Kotler dan Armstrong (2008) bauran pemasaran adalah kumpulan alat pemasaran taktis terkendali yang dipadukan perusahaan untuk menghasilkan respon yang diinginkannya di pasar sasaran. Bauran pemasaran terdiri dari semua hal yang dapat dilakukan perusahaan untuk mempengaruhi permintaan produknya.

a. Produk

Produk adalah sesuatu yang dapat ditawarkan ke pasar untuk mendapatkan perhatian, untuk dibeli, digunakan atau dikonsumsi yang dapat memenuhi suatu keinginan atau kebutuhan. Produk dapat berupa barang fisik, jasa, pengalaman, acara, orang, tempat, properti, organisasi, informasi dan ide (Kotler dan Keller, 2009).

b. Harga 
Menurut Suharno dan Sutarso (2010) harga adalah sejumlah uang yang digunakan untuk mendapatkan barang atau jasa.

c. Tempat

Tempat meliputi kegiatan perusahaan yang membuat produk tersedia bagi konsumen sasaran. (Kottler dan Amstrong, 2008).

d. Promosi

Pengertian promosi menurut Suharno

dan Sutarso (2010) adalah aktivitas komunikasi pemasaran untuk mempengaruhi pasar sasaran agar membeli produk yang dipasarkan.

e. Orang

Orang adalah karyawan atau konsumen lain yang terlibat dalam proses produksi.

f. Proses

Proses adalah metode pengoperasian atau serangkaian tindakan tertentu, yang umumnya berupa langkah-langkah yang diperlukan dalam suatu urutan yang telah ditetapkan.

g. Bukti Fisik

Bukti fisik adalah petunjuk visual atau berwujud lainnya yang memberi bukti atas kualitas jasa, seperti gedung, kendaraan, perabotan interior, perlengkapan, logo, dan petunjuk yang terlihat lainnya yang memberi bukti atas kualitas barang/ jasa.

\section{Definisi $E$-Commerce}

Menurut O'Brien (2005), sistem informasi adalah suatu kombinasi teratur apapun dari people, hardware, software, computer networks and communications, database yang mengumpulkan, mengubah dan menyebarkan informasi di dalam suatu bentuk organisasi. Menurut Laudon dan Laudon (2008) e-commerce adalah suatu proses membeli dan menjual produk-produk secara elektronik oleh konsumen dari perusahaan ke perusahaan dengan komputer sebagai perantara transaksi bisnis. Media yang dapat digunakan dalam aktivitas e-commerce adalah world wide web internet

\section{Komponen E-commerce}

Menurut Hidayat (2008) ada beberapa kelebihan yang dimiliki e-commerce dan tidak dimiliki oleh transaksi bisnis yang dilakukan secara offline, beberapa hal tersebut adalah sebagai berikut ini :

1. Produk: Banyak jenis produk yang bisa dipasarkan dan dijual melalui internet seperti pakain, mobil, sepeda dll.

2. Tempat menjual produk: tempat menjual adalah internet yang berarti harus memiliki domain dan hosting.

3. Cara menerima pesanan: Email, telpon, sms dll.

4. Cara pembayaran: Credit card, paypal, tunai

5. Metode pengiriman: Menggunakan Pos Indonesia, J\&T, atau JNE

6. Customer service: email, Contact us, Telepon, Chat jika tersedia dalam software

\section{Jenis E-commerce}

Penggolongan e-commerce pada umumnya dilakukan berdasarkan sifat transaksinya. Menurut Laudon dan Laudon (2008), penggolongan e-commerce dibedakan sebagai berikut:

1. Business to consumer (B2C),

2. Business to business (B2B).

3. Consumer to consumer $(\mathrm{C} 2 \mathrm{C})$.

4. Peer-to-peer (P2P).

5. Mobile commerce (M-Commerce)

E-commerce yang dimaksud dalam penelitian ini termasuk dalam golongan Business to Consumer (B2C), yang mencakup transaksi jual, beli, dan pemasaran kepada individu pembeli dengan media internet melalui penyedia layanan e-commerce, seperti kaskus, olx, shope, tokopedia dll.

\section{Manajemen Pemasaran}

Kotler dan Keller (2009) mengatakan bahwa pemasaran adalah sebuah proses kemasyarakatan dimana individu dan kelompok memperoleh apa yang mereka butuhkan dan inginkan dengan menciptakan, menawarkan dan secara bebas 
mempertukarkan produk dan jasa yang bernilai dengan orang lain. Sedangkan manajemen pemasaran adalah seni dan ilmu memilih pasar sasaran, meraih, mempertahankan, serta menumbuhkan pelanggan dengan menciptakan, menghantarkan, dan mengkomunikasikan nilai pelanggan yang unggul (Kotler dan Keller, 2009).

\section{Perilaku Konsumen}

Keberhasilan sebuah perusahaan dalam melakukan pemasaran merupakan hal yang penting untuk menciptakan eksistensi perusahaan. Melakukan proses pemasaran bukanlah sebuah hal yang mudah dikarenakan perusahaan harus melihat bagaimana perilaku konsumen yang ada pada pasar yang dikelola.
Menurut Kotler dan Keller (2009) perilaku konsumen adalah studi tentang bagaimana individu, kelompok dan organisasi memilih, membeli, menggunakan, dan bagaimana barang, jasa, ide, atau pengalaman untuk memuaskan kebutuhan dan keinginan mereka. Secara garis besar perusahaan harus memahami bagaimana perilaku konsumen yang dihadapinya, jika ingin tetap eksistensi. Menurut Kotler dan Keller (2009) perilaku pembelian konsumen dipengaruhi oleh faktor budaya, sosial dan pribadi. Faktor budaya memberikan pengaruh yang luas dan dalam. Berikut ini adalah skema model perilaku konsumen,

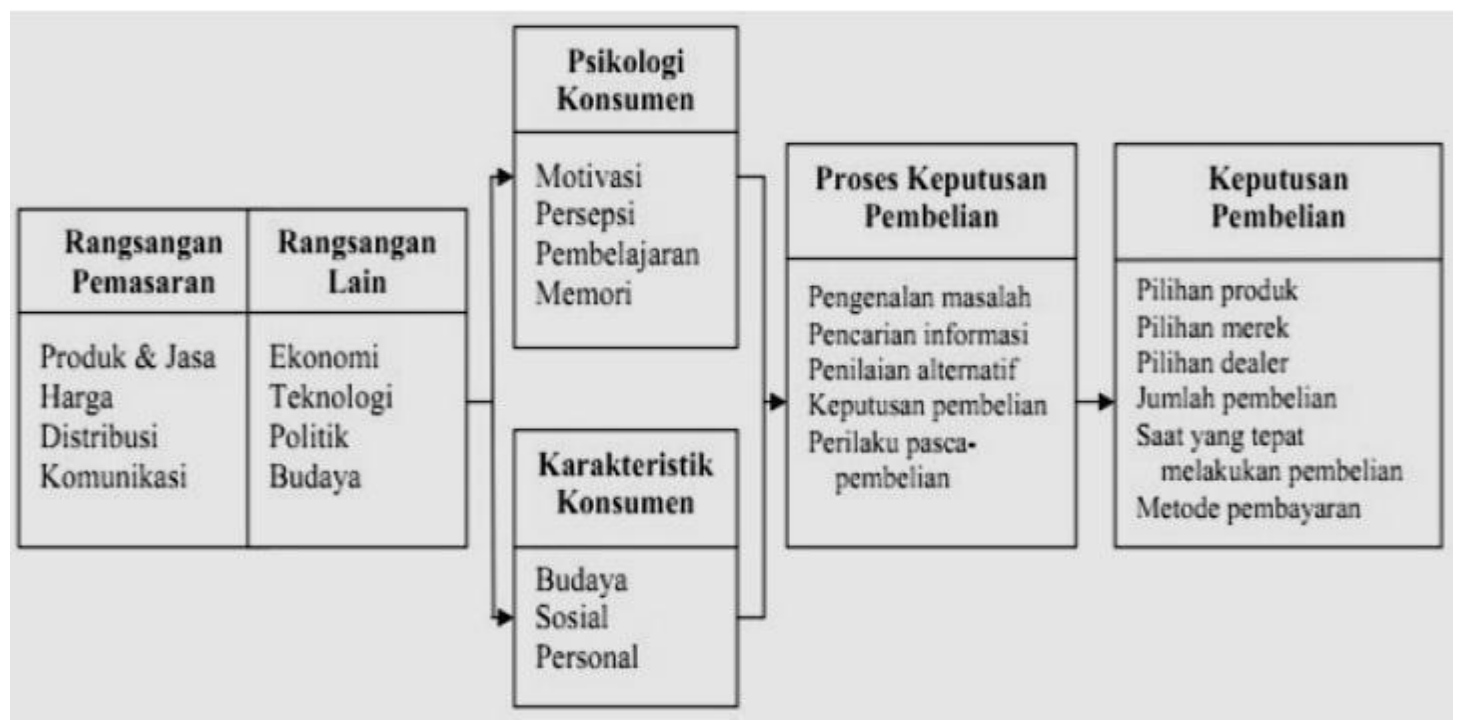

Gambar 1. Model Perilaku Konsumen menurut Kotler dan Keller (2009)

\section{a. Faktor Budaya}

1. Budaya

Budaya adalah determinan dasar keinginan dan perilaku seseorang melalui keluarga dan institusi utama lainnya. Seseorang yang tumbuh memiliki pandangan yang berbeda dengan diri sendiri, hubungan dengan orang lain dan ritual. Setiap perusahaan atau produsen harus benar-benar memperhatikan nilai nilai budaya di setiap Negara untuk memahami cara terbaik memasarkan produk mereka dan mencari peluang untuk produk baru (Kotler dan Keller, 2009).

2. Subbudaya

Setiap budaya terdiri dari beberapa subbudaya yang lebih kecil dimana memberikan identifikasi dan sosialisasi yang lebih spesifik untuk anggota mereka. Subbudaya meliputi

kebangsaan, agama, kelompok, ras dan wilayah geografis. Ketika 
subbudaya tumbuh besar dan cukup kaya, perusahaan sering merancang program pemasaran khusus untuk mereka (Kotler dan Keller, 2009).

3. Kelas Sosial

Hampir seluruh kelompok manusia mengalami stratifikasi sosial. Sering kali dalam bentuk kelas sosial, divisi yang relatif homogen dan bertahan lama dalam sebuah masyarakat, tersusun secara hierarki dan mempunyai anggota yang berbagi nilai, minat dan perilaku yang sama (Kotler dan Keller, 2009). 
Menurut Kotler dan Keller (2009) selain faktor budaya, faktor sosial seperti kelompok referensi, keluarga, serta peran sosial dan status mempengaruhi prilaku pembelian.

1. Kelompok Referensi

Kelompok referensi seseorang adalah semua kelompok yang mempunyai pengaruh langsung atau disebut kelompok primer, dengan siapa seseorang berinteraksi dengan apa adanya secara terus menerus dan tidak resmi, seperti keluarga, teman, tetangga dan rekan kerja.

2. Keluarga

Keluarga adalah organisasi yang penting dalam masyarakat, dan anggota keluarga mempresentasikan kelompok referensi utama yang paling berpengaruh. Terdapat dua keluarga dalam kehidupan pembeli. Keluarga orientasi terdiri dari orang tua dan saudara kandung.

3. Peran dan Status

Seseorang berpatisipasi dalam banyak kelompok-keluarga, klub, dan organisasi. Kelompok sering menjadi sumber informasi dan membantu mendefinisikan norma perilaku. Seseorang dapat mendefinisikan posisinya dalam tiap kelompok dimana ia menjadi anggota berdasarkan peran dan status. Peran terdiri dari kegiatan yang diharapkan seseorang dan dapat dilakukannya. Setiap peran tersebut menyandang status di dalamnya.

Keputusan pembeli juga dipengaruhi oleh karakteristik pribadi. Faktor pribadi meliputi usia dan tahap dalam siklus hidup pembeli; pekerjaan dan ekonomi; kepribadian dan konsep diri; serta gaya hidup dan nilai (Kotler dan Keller, 2009).
1. Usia dan Tahap siklus hidup

Selera seseorang dalam makan, berpakaian dan rekreasi sering berhubungan dengan usia orang tersebut. Konsumsi juga dibentuk oleh siklus hidup keluarga dan jumlah, usia, serta jenis kelamin seseorang dalam rumah tangga dalam satu waktu tertentu.

2. Pekerjaan dan Keadaan Ekonomi

Pekerjaan juga mempengaruhi seseorang dalam memperlihatkan pola konsumsi. Pekerja/ karyawan akan membeli baju kerja, sepatu kerja, dan kotak makanan. Presiden perusahaan akan membeli jas, perjalanan udara, dan keanggotaan country club. Perusahaan atau produsen harus dapat mengidentifikasi kelompok pekerjaan yang mempunyai minat di atas rata-rata terhadap produk dan jasa mereka dan bahkan menghantarkan produk khusus untuk kelompok pekerjaan tertentu.

3. Kepribadian dan Konsep Diri

Setiap orang memiliki karakteristik pribadi yang mempengaruhi perilaku pembeliannya. Kepribadian adalah sekumpulan sifat psikologis manusia yang menyebabkan respon yang relatif konsisten dan tahan lama terhadap rangsangan lingkungan termasuk perilaku pembelian. Kepribadian tersebut sering digambarkan sebagai sifat seperti kepercayaan diri, dominasi, otonomi, rasa hormat, kemampuan bersosialisasi, pertahanan dan kemampuan beradaptasi.

4. Gaya Hidup dan Nilai Orang-orang dari subbudaya, kelas sosial, dan pekerjaan yang sama mungkin memiliki gaya hidup yang cukup berbeda. Gaya hidup adalah pola hidup seseorang yang tercermin dalam kegiatan, minat dan pendapat. 


\section{Psikologi Konsumen}

Rangsangan pemasaran dan kondisi lingkungan ketika memasuki kesadaran konsumen, ditambah sekelompok proses psikologis yang digabungkan dengan karakteristik konsumen tertentu menghasilkan proses pengambilan keputusan dan keputusan akhir pembelian. Tugas perusahaan atau produsen adalah memahami apa yang terjadi dalam kesadaran konsumen ketika adanya rangsangan pemasaran dari luar yang mempengaruhi keputusan pembelian akhir. Empat proses psikologi kunci yaitu motivasi, persepsi, pembelajaran dan memori mempengaruhi respon konsumen secara fundamental (Kotler dan Keller, 2009).

\section{a. Motivasi}

Setiap manusia memiliki kebutuhan yang banyak pada waktu tertentu. Beberapa kebutuhan bersifat biogenik atau kebutuhan itu timbul dari keadaan tekanan psikologis seperti rasa lapar, rasa haus atau rasa tidak nyaman. Kebutuhan lain bersifat psikogenik atau kebutuhan yang timbul dari keadaan tekanan psikologis seperti kebutuhan akan pengakuan, penghargaan atau rasa memiliki (Kotler dan Keller, 2009).

b. Persepsi

Persepsi adalah sebuah proses dimana seseorang memilih, mengatur, dan menerjemahkan masukan informasi untuk menciptakan gambaran tentang sesuatu yang berarti. Poin utamanya adalah persepsi tidak hanya tergantung pada rangsangan fisik, tetapi juga pada hubungan rangsangan terhadap bidang yang mengelilinginya dan kondisi yang ada pada diri seseorang (Kotler dan Keller, 2009).

\section{c. Pembelajaran}

Menurut Kotler dan Keller (2009) mengatakan bahwa pembelajaran mendorong perubahan dalam berperilaku yang didasarkan atas pengalaman. Sebagian besar perilaku manusia dipelajari, meskipun sebagian pembelajaran tersebut tidak disengaja. Ahli teori pembelajaran percaya bahwa pembelajaran dihasilkan melalui interaksi dorongan, rangsangan, pertanda, respon dan penguatan.

\section{d. Memori}

Asosiasi merek terdiri dari semua pikiran, perasaan, persepsi, citra, pengalaman, kepercayaan, sikap dan lainnya yang berkaitan dengan merek. Pemasaran tersebut dilakukan untuk memastikan bahwa konsumen mendapatkan pengalaman produk dan jasa yang tepat untuk menciptakan struktur pengetahuan merek yang tepat dan mempertahankan merek tersebut di dalam memori (Kotler dan Keller, 2009).

\section{Proses Keputusan Pembelian}

Keputusan mencakup suatu pilihan di antara dua atau lebih tindakan alternatif (Peter dan Olson, 2013). Konsumen biasanya melewati lima tahap proses keputusan pembelian, yaitu pengenalan masalah, pencarian informasi, evaluasi alternatif, keputusan pembelian, dan perilaku pasca pembelian. Menurut Kolter dan Keller (2009) proses keputusan pembelian dipengaruhi oleh psikologis dasar dimana hal tersebut berperan penting dalam memahami bagaimana konsumen membuat keputusan pembelian mereka. Proses inti dalam pengambilan keputusan konsumen adalah proses integrasi yang digunakan untuk mengkombinasikan pengetahuan untuk mengevaluasi dua atau lebih perilaku alternatif dan memilih satu diantaranya (Peter dan Olson, 2013).

\section{Keputusan Pembelian Kembali}

Perilaku pembelian kembali berhubungan erat dengan konsep brand loyalty, dimana banyak perusahaan yang mencobanya karena memiliki stabilitas yang tinggi di pangsa pasar. Pembelian kembali biasanya menandakan bahwa produk memenuhi persetujuan konsumen dan bahwa konsumen bersedia memakainya lagi dan dalam jumlah yang lebih besar (Schiffman dan Kanuk, 2010).

Menurut Hawkins, et al dalam Fredereca dan Chairy (2010) mengartikan pembelian 
kembali sebagai suatu kegiatan membeli kembali yang dilakukan oleh konsumen terhadap suatu produk dengan merek yang sama tanpa diikuti oleh perasaan yang berarti terhadap produk tersebut. terdapat dua kemungkinan yang menyebabkan seseorang melakukan pembelian kembali suatu produk. Pertama, konsumen merasa puas dengan pembelian yang mereka lakukan. Kedua, pelanggan merasa tidak puas, tetapi mereka tetap melakukan pembelian kembali.

Di dalam proses keputusan, konsumen tidak akan berhenti hanya sampai proses konsumsi. Konsumen akan melakukan proses evaluasi terhadap konsumsi yang telah dilakukannya. Setelah mengkonsumsi suatu produk atau jasa, konsumen akan memiliki perasaan puas atau tidak puas terhadap produk atau jasa yang dikonsumsinya. Kepuasan akan mendorong konsumen membeli dan mengkonsumsi ulang/kembali produk tersebut, sebaliknya perasaan tidak puas akan menyebabkan konsumen kecewa dan menghentikan pembelian kembali produk tersebut (Sumarwan,2011 dalam Suntoyo, 2013). Berikut ini adalah kerangka pemikiran berdasarkan dasar teori yang ada,

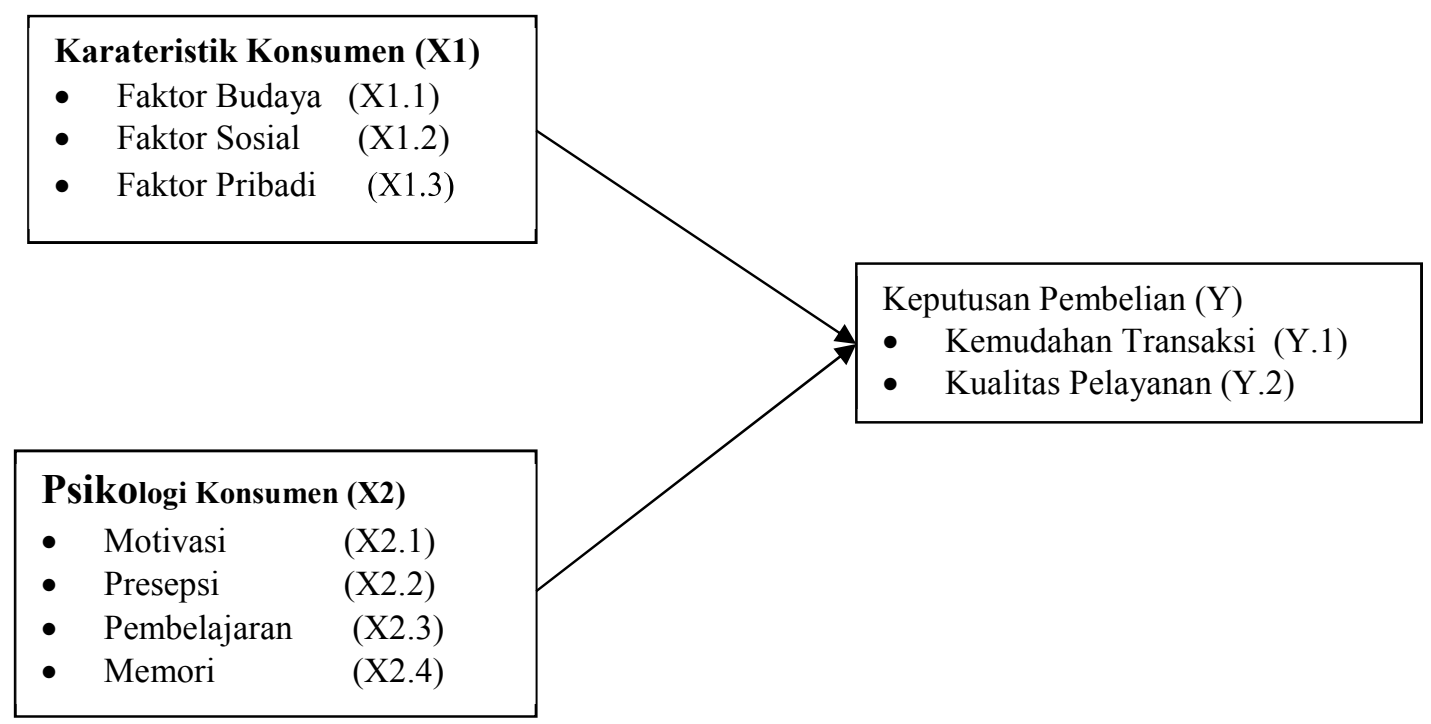

Gambar 2. Kerangka Pemikiran

\section{METODE PENELITIAN / METHODS}

Metode yang digunakan dalam penelitian ini adalah metode kuantitatif. Metode kuantitatif adalah metode berlandaskan pada filsafat positivisme, yang digunakan untuk meneliti populasi atau sampel tertentu dan teknik pengambilan sampel pada umumnya dilakukan secara random, pengumpulan data menggunakan instrument penelitian, analisis data bersifat kuantitatif/statistik dengan tujuan untuk menguji hipotesis yang telah ditetapkan. Jumlah sampel dalam penelitian ini adalah 200 mahasiswa di Surabaya yang pernah melakukan pembelian dengan e-commerce. Teknik pengambilan sampel pada penelitian ini menggunakan teknik accidental sampling. Menurut Sugiyono (2015) teknik accidental sampling adalah teknik pengambilan sampel yang tidak ditetapkan dan direncanakan lebih dahulu, jumlah sampel yang dikehenadaki tidak berdasrkan pertimbangan yang dapat dipertanggung jawabkan, asal memenuhi keperluan saja, setelah jumlah sampel mencukupi pengambilan data dihentikan. 
Penelitian ini menggunakan skala likert dalam pengukurannya dari pertanyaan yang diberikan kepada responden (Sugiyono, 2015). Teknik analisis yang digunakan adalah analisis regresi linier berganda menggunakan SPSS, dengan persamaan sebagai berikut

$$
\mathbf{Y}=\mathbf{a}+\mathbf{b} 1 \mathbf{X} 1+\mathbf{b} 2 \mathrm{X} 2
$$

$\mathrm{H} 1=$ Karateristik konsumen dan psikologi konsumen berpengaruh secara parsial terhadap keputusan pembelian kembali menggunakan e-commerce

$\mathrm{H} 2=$ Karateristik konsumen dan psikologi konsumen berpengaruh secara simultan terhadap keputusan pembelian kembali menggunakan e-commerce

\section{HASIL PENELITIAN DAN DISKUSI}

Karateristik konsumen pada penelitian ini diukur dengan faktor budaya, faktor sosial dan faktor pribadi. Hasil dari responden menunjukkan bahwa presentase tertinggi dari dari masing-masing 3 faktor tersebut adalah $42,5 \%$ responden sangat setuju adanya pengaruh faktor budaya dalam mempengaruhi keputusan pembelian kembali menggunakan $e$ commerce. Faktor sosial sebesar 45,5\% menyatakan setuju adanya pengaruh untuk menentukan keputusan pembelian kembali mengunakan e-commerce. Faktor pribadi sebesar 55\% setuju dalam mempengaruhi keputusan pembelian kembali menggunakan $e$ commerce.

Psikologi konsumen pada penelitian ini diukur dengan motivasi, presepsi, pembelajaran dan memori. Hasil dari responden menunjukkan bahwa presentase tertinggi dari masing-masing 4 faktor tersebut adalah 59\% responden setuju adanya pengaruh motivasi dalam mempengaruhi keputusan pembelian kembali menggunakan e-commerce. Presepsi sebesar $56 \%$ setuju adanya pengaruh untuk menentukan keputusan pembelian kembali mengunakan $e$ commerce. Pembelajaran sebesar $49,5 \%$ setuju dalam mempengaruhi keputusan pembelian kembali menggunakan e-commerce. Serta memori sebesar $53 \%$ setuju dalam mempengaruhi keputusan pembelian kembali menggunakan e-commerce

Variabel dependent pada penelitian ini diukur menggunakan kemudahan bertransaksi dan kualitas pelayanan. 59,5\% responden setuju dengan kemudahan bertransaksi dengan pembelian menggunakan e-commerce. Dan $65 \%$ menyatakan setuju dengan kualitas pelayanan yang baik, ketika melakukan pembelian menggunakan e-commerce.

Koefisien determinasi pada penelitian ini dapat dilihat dari Adjusted $R$ Square, menunjukkan bahwa dalam penelitian ini karateristik konsumen dan psikologi konsumen berpengaruh sebesar 27\% terhadap keputusan pembelian kembali menggunakan e-commerce, sedangkan $73 \%$ dipengaruhi oleh variabel lain yang tidak diteliti dalam penelitian ini. Hipotesis (H2) diterima karena karateristik konsumen dan psikologi konsumen berpengaruh secara simultan terhadap keputusan pembelian kembali menggunakan $e$ commerce dengan nilai signifikan sebesar 0,026 atau kurang dari nilai signifikasi 0,05. Sedangkan hipotesis (H1) ditolak karena karateristik konsumen dan psikologi konsumen tidak berpengaruh secara parsial terhadap keputusan pembelian kembali menggunakan $e$ commerce, karena nilai signifikan psikologi konsumen $>0,05$ atau sebesar 0,183. 
Tabel 1. Hasil Analisis SPSS

Model Summary

\begin{tabular}{|c|c|c|c|c|c|c|c|c|}
\hline \multirow[b]{2}{*}{ Model } & \multirow[b]{2}{*}{$\mathrm{R}$} & \multirow[b]{2}{*}{$\begin{array}{c}\mathrm{R} \\
\text { Square }\end{array}$} & \multirow[b]{2}{*}{$\begin{array}{l}\text { Adjusted } \\
\text { R Square }\end{array}$} & \multirow[b]{2}{*}{$\begin{array}{l}\text { Std. Error of } \\
\text { the Estimate }\end{array}$} & \multicolumn{4}{|c|}{ Change Statistics } \\
\hline & & & & & $\begin{array}{l}\text { R Square } \\
\text { Change }\end{array}$ & F Change & \begin{tabular}{r|r}
$\mathrm{df}$ & \\
1 & $\mathrm{df} 2$
\end{tabular} & $\begin{array}{l}\text { Sig. F } \\
\text { Change }\end{array}$ \\
\hline 1 & $.191^{\mathrm{a}}$ & .036 & .027 & .97914 & .036 & 3.710 & \begin{tabular}{l|l}
2 & 197
\end{tabular} & .026 \\
\hline
\end{tabular}

Didapatkan faktor budaya, faktor sosial dan faktor pribadi memiliki peran penting yang dirasakan oleh responden dalam mengambil keputusan pembelian kembali menggunakan $e$ commerce. Faktor Budaya memiliki persentase sangat setuju paling besar $(42,5 \%)$ hal tersebut menunjukkan bahwa faktor budaya memiliki peranan paling besar yang dirasakan oleh konsumen, hal ini diperkuat dengan adanya teori dimana perilaku pembelian konsumen dipengaruhi oleh faktor budaya, sosial dan pribadi dan faktor budaya memberikan pengaruh yang luas dan dalam (Kotler dan Keller, 2009). Dalam memilih keputusan pembelian kembali menggunakan e-commerce responden mempertimbangkan untuk memilih kemudahan untuk bertransaksi dan kualitas pelayanan yang baik. Karena faktor budaya kita menekankan pada tata cara dan saling menghormati untuk sesorang, hal ini didukung oleh Adisaputro (2010) dimana masing-masing strata sosial menunjukkan kelas tertentu yang anggotanya menghormati nilai-nilai yang sama, perhatian, dan perilaku sosial. Penelitian ini menggunakan kota Surabaya sebagai riset penelitian, sehingga faktor sosial biasanya dipengaruhi oleh teknologi informasi yang digunakan oleh responden. Suntoyo (2013) menyatakan bahwa individu yang relatif sadar akan perbedaan kelas akan lebih mungkin berasal dari kelas yang lebih tinggi, walaupun individu dari kelas sosial lebih rendah, mungkin akan lebih sadar atas realitas kelas sosial secara keseluruhan.

Faktor psikologi dipengaruhi oleh motivasi, persepsi, pembelajaran dan memori yang berperan besar dalam diri responden dalam pengambilan keputusan pembelian kembali menggunakan e-commerce. Responden secra psikologi lebih banyak setuju dalam memilih keputusan pembelian kembali menggunakan e-commerce, karena responden dapat membeli produk sesuai dengan kebutuhan mereka dan sesuai dengan selera mereka, disamping itu pula mereka merasa mudah menggunakan e-commerce dalam memilih keputusan pembelian kembali, karena memudahkan mereka dalam memilih dan dapat menghemat waktu. Konsumen akan mengingat selalu e-commerce yang memiliki kualitas pelayanan yang baik serta kemudahan bertransaksi, karena e-commerce tersebut telah dipercaya dan banyak direkomendasikan sebelumnya. Hasil tersebut berkaitan dengan teori yaitu ketika konsumen memiliki keterlibatan yang sama terhadap produk, mereka sering membeli merek yang berbeda karena alasan yang berbeda. Informasi yang mereka kumpulkan, cara mereka memproses dan menjabarkannya, serta evaluasi mereka terhadap merek-merek alternatif semuanya dipengaruhi oleh karakteristik psikologi (Boyd, et al, 2000). Dan keputusan pembelian kembali oleh konsumen sangat ditentukan oleh kepercayaan pada toko online e-commerce (Hallikainen and Laukkanen, 2017). 
Pembelajaran memiliki persentase setuju sebesar 49,5\% dalam melakukan keputusan kembali menggunakan e-commerce, yang dirasakan oleh responden dimana mereka lebih terdorong untuk memilih produk yang telah banyak direkomendasikan dan memilih ecommerce yang memiliki kulaitas peayanan terbaik, kemudahan transaksi dan terpercaya untuk menghemat waktu. Hal tersebut dapat dijelaskan pula dengan adanya teori dimana pembelajaran mendorong perubahan dalam berperilaku yang didasarkan atas pengalaman. Sebagian besar perilaku manusia dipelajari, meskipun sebagian pembelajaran tersebut tidak disengaja. Ahli teori pembelajaran percaya bahwa pembelajaran dihasilkan melalui interaksi dorongan, rangsangan, pertanda, respons, dan penguatan (Kotler dan Keller, 2009).

Keputusan pembelian kembali dipengaruhi sebesar $65 \%$ dalam hal melakukan pelayanan yang terbaik, sehingga banyak responden yang merasa puas dengan membeli produk menggunakan e-commerce dan produk yang dibeli sesuai dengan harapan mereka dan banyak pula dari mereka akan melakukan pembelian kembali produk melalui $e$ commerce. Hasil tersebut sesuai dengan teori yang ada diaman pembelian kembali biasanya menandakan bahwa produk memenuhi persetujuan konsumen dan bahwa konsumen bersedia memakainya lagi dan dalam jumlah yang lebih besar (Schiffman dan Kanuk, 2010). Menurut Hawkins et al dalam Fredereca dan Chairy (2010) mengartikan pembelian kembali sebagai suatu kegiatan membeli kembali yang dilakukan oleh konsumen terhadap suatu produk dengan merek yang sama tanpa diikuti oleh perasaan yang berarti terhadap produk tersebut.

\section{SIMPULAN}

Berdasarkan analisis penelitian pada penelitian ini dan uji hipotesis yang telah dilakukan, maka karakteristik konsumen dan psikologi konsumen berpengaruh signifikan secara simultan terhadap keputusan pembelian kembali. Sedangkan karateristik konsumen dan psikologi konsumen tidak berpengaruh secara parsial terhadap keputusan pembelian kembali menggunakan e-commerce, karena nilai signifikan psikologi konsumen $>0,05$ karateristik konsumen dan psikologi konsumen berpengaruh sebesar $27 \%$ terhadap keputusan pembelian kembali menggunakan e-commerce, sedangkan $73 \%$ dipengaruhi oleh variabel lain yang tidak diteliti dalam penelitian ini.

\section{DAFTAR PUSTAKA / REFERENCE}

Adisaputro, Gunawan. 2010. Manajemen Pemasaran: Analisis Untuk Perancangan Strategi Pemasaran, Edisi Pertama. Yogyakarta: YKPN.

Boyd, Jr. Harper W., Walker, Jr. Orville C., and Larreche, Jean-Claude. (2000). Manajemen Pemasaran : Suatu Pendekatan Strategis dengan Orientasi Global. Jakarta: Erlangga.

Fredereca, Bunga Geofanny dan Chairy. 2010. Pengaruh Psikologi Konsumen Terhadap Keputusan Pembelian Kembali Smartphone Blackberry. Jurnal Manajemen Teori Dan Terapan, Tahun 3, No. 2, Agustus 2010. Universitas Tarumanegara. Jakarta.

Hallikainen, H. and Laukkanen, T. 2017. National culture and consumer trust in e-commerce. International Journal of Information Management 38 (2018) 97-106

Hidayat,Taufik. 2008. Panduan MembuatToko Online Dengan Oscommerce, Jakarta :Mediakita

J. Paul Peter dan Jerry C. Olson. 2013. Perilaku Konsumen Dan Strategi Pemasaran. Jakarta : Salemba Empat.

Kotler, P dan Gary Armstrong. 2008. PrinsipPrinsip Pemasaran. Edisi Ke-12 Jilid 1. Jakarta : Erlangga

Kotler, Philip dan Keller, Kevin Lane. 2009. Manajemen Pemasaran, Edisi 13 Jilid 1. Jakarta: Erlangga 
Balance Vol.XVI No. 1 | Januari 2019

Laudon, Kenneth C. dan Jane P. Laudon 2008. Sistem Informasi Manajemen: Mengelola Perusahaan Digital Buku Satu Edisi. Depok. Salemba Empat

O’Brien, James. A. 2005. Pengantar Sistem Informasi Perseptif Bisnis Dan Manajerial. Salemba.

Schiffman, Leon G. dan Kanuk, Leslie Lazar. 2010. Consumer Behavior, Tenth Edition. New Jersey: Pearson Education, Inc.

Sugiyono. 2015. Metode Penelitian \& Pengembangan (Research And Development). Bidang :
Pendidikan, Manajemen, Sosial, Dan Teknik. Alfabeta Bandung.

Suharno dan Yudi Sutarso. 2010. Marketing In Practice. Yogyakarta : Graha Ilmu

Suntoyo, Danang. 2013. Perilaku Konsumen (Panduan Riset Sederhana Untuk Menggali Konsumen). Yogyakarta: CAPS. 